OPEN ACCESS

Vol. 8, No. 2, Oktober, 2020

Page. 85-95

DOI: https://doi.org/10.21107/jaffa.v8i2.8773
JOURNAL OF AUDITING, FINANCE, AND FORENSIC ACCOUNTING

E-ISSN: 2461-0607 ISSN: 2339-2886

https://journal.trunojoyo.ac.id/jaffa

\title{
Effect of Pressure, Opportunity, Rationalizations, Capability and Arrogance in The Concept of The Fraud Pentagon
}

1Neng Putriyanti*; ${ }^{2}$ Ari Dewi Cahyati

${ }^{12}$ Accounting Department, Islamic University 45 Bekasi, Indonesia

\section{Article Info:}

Received: 05 October 2020

in revised form: 21 October 2020

Accepted: 23 October 2020

Available Online: 29 October 2020

\section{Keywords:}

Fraud pentagon, pressure, opportunity, rationalizations, capability, arrogance, Fraud in financial statement.

\section{Corresponding Author*:}

*Email: aridewicahyati@gmail.com

\begin{abstract}
The purpose of this study was to determine whether the elements in the fraud pentagon concept could detect the potential for fraud in financial statements. The sample in this research is state-owned companies (BUMN) listed on the Indonesia Stock Exchange (BEI) in 20142018. The sampling method used was purposive sampling technique. The analytical tool in this research uses the logistic regression analysis method. The results showed that the variables pressure and rationalizations had a significant positive effect on fraudulent financial reporting. The opportunity variable has a significant negative effect on fraudulent financial reporting. Meanwhile, the pressure variable, opportunity variable, capability variable, and arrogance variable had a positive and insignificant effect on fraudulent financial statements.
\end{abstract}

Abstrak; Tujuan dari penelitian ini adalah untuk mengetahui apakah unsur-unsur dalam konsep fraud pentagon dapat mendeteksi potensi terjadinya kecurangan terhadap laporan keuangan. Sampel dalam riset ini adalah perusahaan milik negara (BUMN) yang terdaftar di Bursa Efek Indonesia (BEI) tahun 20142018. Metode penentuan sampel menggunakan teknik purposive sampling. Alat analisis dalam riset ini menggunakan metode analisis regresi logistik. Hasil penelitian menunjukkan bahwa variabel pressure, rationalizations berpengaruh positif signifikan terhadap fraudulent financial reporting. Variabel opportunity berpengaruh negatif signifikan terhadap fraudulent financial reporting. Sedangkan Variabel pressure, variabel opportunity, variabel capability, dan variabel arrogance berpengaruh positif tidak signifikan terhadap kecurangan laporan keuangan. 


\section{INTRODUCTION}

Fraud has become a global phenomenon that occurs in several countries in various industrial sectors. Contamination of accounting values cannot be avoided along with the occurrence of these deviations. Manipulation of various material information in a financial report can mislead users of financial statements and lead investors to make wrong investment decisions, which as a result can cause losses to get a return on investment (Ulfah., Et. Al., 2017)

The publication report mentioned in Report to The Nation Global Edition (2018) can be seen that fraud cases are most often committed in the form of asset misappropriations with a percentage of $89 \%, 38 \%$ in the form of corruption, and $10 \%$ in the form of fraudulent financial statements. (financial statement fraud). The report also shows that for the types of fraud, asset misuse (asset misappropriation) and corruption (corruption) experienced fluctuations in 2014-2018. Meanwhile, the type of fraud in the form of financial statement fraud continued to increase, although not in a significant amount.

Meanwhile, based on the same ACFE publication report, namely Report to The Nation Global Edition (2018), it shows that the type of financial statement fraud has the largest impact on financial losses with a nominal value of USD 800,000, corruption is in second place with losses incurred of USD 250,000, and the type of asset misuse fraud ranked last with a loss incurred of USD 114,000. Based on these data, it can be concluded that although the type of financial statement fraud has the lowest percentage in the fraud risk category based on the frequency of occurrence, the impact of financial losses incurred is much greater than the losses caused by other types of fraud, namely misuse. assets (asset misappropriation) and corruption (corruption).

The increasing prevalence of fraudulent practices on financial reports in various industrial sectors is not a good thing, therefore action is needed to minimize the occurrence of fraud. Actions that can be taken to minimize the occurrence of fraud are by making efforts to detect fraudulent practices as early as possible to prevent cases of fraud that cause major losses to various parties. Various theories can be used to detect the occurrence of fraud, such as the fraud triangle, fraud diamond, and the fraud pentagon. Exposure to data and cases related to fraudulent practices as well as the existence of research gaps from previous research are the reasons why the author wants to carry out further research with the title "The Influence of Pressure, Opportunity, Rationalizations, Capability and Arrogance in the Pentagon's Fraud Concept on Financial Statement Fraud in State-Owned Enterprises. listed on the Indonesia Stock Exchange ".

\section{LITERATURE REVIEW AND HYPOTHESES DEVELOPMENT}

\section{Agency Theory}

Agency theory describes the existence of a collaborative connection between shareholders as principal and management as an agent. The relationship between the principal (owner) and the agent (management) arises (Jensen and Meckling, 1976).

When several parties are bound by a contract and agree to cooperate, a conflict of interest between the parties cannot be avoided. The parties in this case, namely the principal and agent. Conflict of interest occurs as a result of differences in interests between principal and agent. The increase in the company's financial performance in the form of a high rate of return on the investment that has been made is the expectation of the principal, while the agent expects high compensation for every work that has been done (Amara, Amar, and Jarboui, 2013)

\section{Fraud Pentagon}

Based on the opinion of Albrecht et al. in Annisya (2016) states that fraud (fraud) is an action that can be said to be general in nature where a person designs ingenious actions to benefit himself by means of the wrong presentation.

\section{Pentagon Fraud Theory}

Crowe Howarth (20110) proposes the fraud pentagon theory which is the development of the previous theory from the fraud triange theory and the fraud diamond theory. The element added to the fraud pentagon theory is arrogance 


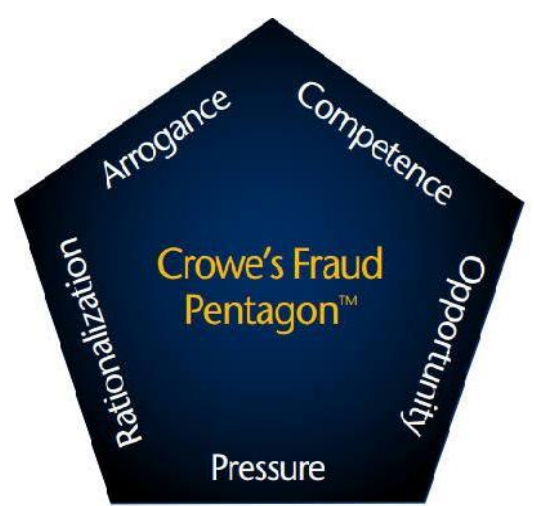

Figur 1 Fraud Pentagon

Source: Howarth (2011)

\section{Hypothesis Development \\ Effect of Pressure on fraudulent financial statements}

The benchmark for financial stability can be seen from financial stability. Companies that have economic stability will be more trusted by investors, creditors and the public. Investors and creditors will doubt the condition of a company that does not have good financial stability. so that it will hamper the flow of funds from investors in the future. This situation will make management feel depressed, because management acting as an agent may have personal interests such as maximizing his personal wealth by getting compensation from the company for his work. The existence of a conflict of interest between the principal and the agent will cause agency problems. Management tends to prioritize opportunistic interests (Eisenhardt, 1989). Then management will manipulate the financial statements in various ways so that the company's financial stability remains stable.

Skousen et. Al. (2009) show that the greater the ratio of changes in total assets (ACHANGE has a positive effect on the potential for financial statement fraud. This is in line with Sihombing and Raharjo (2014) and Siddiq et. Al. (2017) which state that financial stability has a significant effect on financial stability. fraudulent financial reporting.

H1a: Financial stability has an effect on fraudulent financial statements

External pressure is the condition of the company under pressure from outside the company. Skousen et al. (2008) stated that one of the sources of external pressure is an increase in demand for funding sources to improve performance, but the company has difficulty meeting credit requirements and there are concerns that the company will not be able to repay its debt at maturity.

External Pressure is calculated using the leverage ratio, which is the ratio of total debt divided by total assets. The higher the leverage ratio, the higher the potential for management to commit fraud on financial statements. This is in accordance with their research (2008), Sihombing and Raharjo (2014), and Tessa and Raharja (2016) which state that external pressure proxied by LEV has a significant positive effect on fraudulent financial reporting.

H1b: External pressure has an effect on fraudulent financial statements

\section{Effect of Opportunity on fraudulent financial statements}

Agency theory explains that fraud can be triggered by a conflict of interest between the principal and agent. If there is no conflict of interest, the agent will act as expected by the principal, even though there is no supervision. However, because agents tend to be self-interest, the principal cannot be completely sure whether the agent acts in accordance with the agreed cooperation contract or not (Eisenhardt, 1989). Therefore, supervision of the agent is needed, because with the conflict of interest between the agent and the principal, the lack of effective supervision function can be used as an opportunity to maximize the agent's personal interests.

Opportunities for committing fraud can be caused by weak supervision or ineffective monitoring functions in a company (effective monitoring). Supervisory 
mechanisms in companies can be implemented to minimize fraud, one of which is the presence of an independent board of commissioners whose functions: 1) ensure the implementation of corporate strategy, 2) supervise management in managing the company and ensure accountability (Forum for Corporate Governance in Indonesia, 2003). Beasley and Salterio (2001) quoted by Sihombing and Rahardjo (2004) concluded that the supervision of management is more effective with the functioning of the board of commissioners.

This is supported by research by Putriasih, Hermawan, and Wahyuni (2016, Skousen er.al (2009), which states that effective monitoring has an effect or can be used to detect fraudulent financial statements.

H2a: effective monitoring has an effect on fraudulent financial statements.

Agency theory explains that agents run the company directly, so that they have more information than the principal. Due to the information asymmetry, it makes it difficult for the principal to know what the agent is actually doing. This encourages the agent to provide information that is not in accordance with the actual situation (Scott, 2017) in Rini (2012).

Summer and Sweeney in Sihomding and Rahardjo (2014) reveal that accounts receivable and inventory involve judgment in assessing the allowance for losses of accounts receivable and authorization where the judgment is subjective in nature that management can use to manipulate financial statements. Summer and Sweeney in Sihombing and Rahardjo (2014) found differences in accounts receivable and inventory at companies that commit fraud and those that do not.

H2b: Nature of industry influence on fraudulent financial statements

\section{The effect of rationalizations on fraudulent financial statements}

Agency theory explains that management as a trusted party tends to prioritize their personal interests. Francis and Krishnan (1999) and Vermeer (2003) in Sihombing and Rahardjo (2014) state that the insight into rationalization in financial statements is influenced by the accrual principle. Skousen (2009) states that total accruals can be used to describe the rationalization associated with management's use of the accrual principle. Total accruals are calculated as changes in working capital, less changes in cash, less changes in tax payable, less changes in depreciation and amortization expenses, then divided by total assets.

Skousen (2009) suggests that the measurement of rationalization can use total accruals. Research from Sihombing and Rahardjo (2014) states that rationalization which is proxied by total accruals has an effect on fraudulent financial reporting.

H3: Total accruals have an effect on fraudulent financial statements

\section{The effect of capability on financial statement fraud}

In addition to conflicts of interest, conflicts are also caused by an imbalance of information between the agent and the principal. Wollfe and Hermanson (2004) say that people who understand and know how to take advantage of opportunities are likely to commit fraud. Characteristic elements in someone doing something wrong are: position / function brains, confidence / ego, coercion skills, effective lying and immunity to stress (Wolfe and Hermason, 2004). Based on these characteristics, the position of the CEO, directors, and heads of other divisions can be a determining factor for the occurrence of fraud, by taking advantage of their position that can influence others in order to expedite the act of fraud.

Wolfe and Hermanson (2004) in Tessa and Harto (2016) state that stress periods can be caused by a change of directors which has an impact on opening up opportunities to commit fraudulent practices. This statement is supported by research from Putriasih et. al. (2016), Bayagub et al., (2018), and Shiddiq et al. (2017), which states that financial statement fraud is influenced by capability, which is proxied by changes in directors $\mathrm{H} 4$ : Changes in directors have an effect on fraudulent financial statements.

\section{The effect of arrogance on fraudulent financial statements}

Crowe Howart (2011) states that arrogance is a trait of superiority for criminals who feel that they do not need to comply with any internal controls or policies implemented by the company and one of the factors that drives this attitude is because of the fear of losing 
their position, status, and so on. . This is related to the narcissistic theory presented by Sigmund Freud. This arrogance can be seen from Kartono (2000) which states that individuals with narcissistic personalities will consider themselves very superior and very important, there is extreme self-importancy, they consider themselves the smartest, the most powerful, the most powerful, and the most everything. Arrogance and narcissism can be reflected. with the Frequent number of CEO's picture, which describes the number of photos. Profiles, achievements or other information regarding the track record of the CEO which is repeatedly presented in the annual report of Simon et. al. (2015)

This statement is also supported by the results of research conducted by Tessa and Harto (2016), as well as Arisandi and Verawati (2017). Frequent number of CEO's picture has a significant positive effect in detecting fraudulent financial statements, meaning that more CEO photos are included in the company's annual report the higher the likelihood of financial statement fraud at the company.

H5: The number of CEO photos included in the annual report has an effect on fraudulent financial statements

\section{RESEARCH METHODOLOGY}

\section{Types of research}

This research is a quantitative research. The research data is secondary data in the 2014-2018 period.

\section{Population and Research Sample}

The population used in this research is a company that is a state-owned company (BUMN) that has been listed on the Indonesia Stock Exchange in the period 2014 to 2018. Sampling was carried out based on the purposive sampling method. The sample criteria used in this study include: 1) Companies that are state-owned companies (BUMN) that have published are listed on the Indonesia Stock Exchange in the period 2014 to 2018.2) the company has complete data used to calculate the research variables presented with complete.

\section{Operational Variables \\ Dependent Variable}

The dependent variable or dependent variable is a variable that is influenced by the independent variable. The dependent variable used in this study is fraudulent financial statements. This study detects fraudulent financial reporting using the M-score model (Hammod et. Al., 2018), with the following formula:

$-4,84+0,920 D S R I+0,528 G M I+0,404 A Q I+0,892 S G I+0,115 D E P I-0,172 S G A I-0,327 L V G I+$ 4,697TATA M-Score $=$

Dummy:

a. $0=$ Beneish M-Score <-2.22, the company does not indicate fraudulent financial reporting or is classified as non-fraud.

b. 1 = Beneish M-Score> -2.22, the company is indicated to have committed fraudulent financial reporting or is classified as fraud.

Tabel 1 Variabel Independen

\begin{tabular}{|l|l|c|}
\hline No & \multicolumn{1}{|c|}{ Research Variables } & Measurement \\
\hline 1. & $\begin{array}{l}\text { Financial Stability (ACHANGE) based on } \\
\text { research conducted by Skousen et., Al } \\
(2009)\end{array}$ & $=\frac{1 \text { Total aset }(t)-\text { Total Aset }(t-1)}{\text { Total Aset }(t-1)}$ \\
\hline 2. & $\begin{array}{l}\text { External Pressure (LEV) based on research } \\
\text { conducted by Skousen et., Al (2009). }\end{array}$ & LEV $=\frac{\text { Total Liabilitas }}{\text { Total Aset }}$ \\
\hline
\end{tabular}




\begin{tabular}{|c|c|c|}
\hline 3. & $\begin{array}{l}\text { Ineffective Monitoring (BDOUT) based on the } \\
\text { research conducted } \\
\text { by Skousen (2009) }\end{array}$ & $=\frac{\text { BDOUT }}{\text { Jumlah dewan komisaris independen }}$ \\
\hline 4. & $\begin{array}{l}\text { Nature of Industry (INVENTORY) based on } \\
\text { research conducted by Skousen } \\
\text { (2009). }\end{array}$ & $\begin{aligned} \text { INVENTORY }= & \frac{\text { Inventory }(t)}{\text { Sales }(t)} \\
& -\frac{\text { Inventory }(t-1)}{\text { Sales }(t-1)}\end{aligned}$ \\
\hline 5. & $\begin{array}{l}\text { Total Accruals (TATA) based on research } \\
\text { conducted by Skousen } \\
(2009) \text {. }\end{array}$ & $\begin{array}{l}\text { TATA } \\
=\frac{\Delta \text { Working CApital }-\Delta \text { Cash }-\Delta \text { Tax Pay }}{\text { Total Assets }}\end{array}$ \\
\hline 6. & $\begin{array}{l}\text { Change in Director (DCHANGE) based on } \\
\text { research from } \\
\text { Tessa and Harto (2016) and Sihombing and } \\
\text { Rahardjo } \\
\text { (2014) DCHANGE is measured by a dummy } \\
\text { variable where if there is a change in the } \\
\text { company's directors every year during the } \\
2014-2018 \text { period then it is given code } 1 \text {, if } \\
\text { there is no change in the company's } \\
\text { directors during the 2015-2018 period then } \\
\text { it is coded } 0\end{array}$ & $\begin{array}{l}\text { DCHANGE is measured by a dummy } \\
\text { variable where if there is a change in } \\
\text { the company's directors every year } \\
\text { during the } 2014-2018 \text { period then it } \\
\text { is given code } 1 \text {, if there is no change } \\
\text { in the company's directors during the } \\
2015-2018 \text { period then it is coded } 0\end{array}$ \\
\hline 7. & $\begin{array}{l}\text { The frequent number of CEOs is based on } \\
\text { research from Tessa and Harto (2016) and } \\
\text { Siddiq et., Al (2017). }\end{array}$ & $\begin{array}{l}\text { The ratio used to measure the effect of } \\
\text { arrogance on fraudulent financial } \\
\text { statements is the large number of } \\
\text { CEO photos displayed on the } \\
\text { company's annual report }\end{array}$ \\
\hline
\end{tabular}

\section{Method of Analysis}

The logistic regression model used in this study are:

$\mathrm{FFR}=\alpha+\beta 1 \mathrm{ACHANGE}+\beta 2 \mathrm{LEV}+\beta 3 \mathrm{BDOUT}+\beta 4 \mathrm{INVENTORY}+\beta 5 \mathrm{TATA}+$ $\beta 6$ DCHANGE $+\beta 7$ CEOPIC $+e$

$\begin{array}{ll}\text { FFR } & =\text { Ftaudulent Financial Reporting } \\ \mathrm{a} & =\text { Konstanta } \\ \beta & =\text { Koefisien Variabel } \\ \text { ACHANGE } & =\text { Financial Stability } \\ \text { LEV } & =\text { External Pressure } \\ \text { BDOUT } & =\text { Ineffective Monitoring } \\ \text { INVENTORY } & =\text { Nature of Industry } \\ \text { TATA } & =\text { Total Accrual } \\ \text { DCHANGE } & =\text { Change in Director } \\ \text { CEOPIC } & =\text { Frequent number of CEO's Picture }\end{array}$




\section{FINDINGS AND DISCUSSION}

\section{Tabel 2 Testing the Eligibility of the Regression Model Hosmer and Lemeshow Test}

\begin{tabular}{|l|l|l|l|}
\hline Step & Chi-square & Df & Sig. \\
\hline 1 & 5.954 & 8 & .652 \\
\hline
\end{tabular}

Source: SPSS 23, output Results, 2020

From the results of the hosmer and lemeshow test in the table above, the chisquare value is 5,954 with a significance (p) of 0.652 . Based on these results, with a significance value greater than 0.05 ( $>$ > 0.05), it can be concluded that the model can predict its observation value or the model is said to be fit with the data and the model is acceptable, so this regression model can be used for further analysis.

\section{Assessing the Overall Model (Overall Model Fit)}

The overall Model Fit test or the overall model test is conducted to test the independent variables in the logistic regression simultaneously or simultaneously affecting the dependent variable.

Table 3 Test Results Assessing the Overall Model

\begin{tabular}{|l|l|l|l|}
\hline \multicolumn{2}{|c|}{ Iteration } & \multicolumn{1}{|c|}{$\mathbf{- 2}$ Log likelihood } & Coefficients \\
\cline { 4 - 4 } & & & Constant \\
\hline 2 & 1 & 110.854 & -.050 \\
& 110.854 & -.050 \\
\hline
\end{tabular}

Source: SPSS 23 Output Results, 2020

Table 3 shows the value of -2 Log Likelihood in the first block (block number $=0$ ), it can be seen that the -2 Log Likelihood value is 110,854 .

Tabel 4 Determination Coefficient Test Results Model Summary

\begin{tabular}{|c|c|c|c|}
\hline Step & $\begin{array}{c}-2 \text { Log } \\
\text { likelihood }\end{array}$ & $\begin{array}{c}\text { Cox \& Snell } \\
\text { R Square }\end{array}$ & $\begin{array}{c}\text { Nagelkerke } \\
\text { R Square }\end{array}$ \\
\hline 1 & $72.615^{\mathrm{a}}$ & .380 & .507 \\
\hline
\end{tabular}

a. Estimation terminated at iteration number 6 because parameter estimates changed by less than, 001 .

Source: SPSS 23 Output Results, 2020

Based on the results of the SPSS output for the coefficient of determination, it can be seen that the Nagelkerke R Square value is 0.507 . This means that the variability of the dependent variable which can be explained by the independent variables is $50.7 \%$, while the remaining $49.3 \%$ is explained by other variables outside the research.

Tabel 5 Classification Matrix Test

\begin{tabular}{|c|c|c|c|c|c|}
\hline & & & Predicted & & \\
\hline & Obse & & FFR & & Percentage \\
\hline & & & NON FRAUD & FRAUD & Correct \\
\hline Step 1 & FFR & NON FRAUD & 35 & 6 & 85.4 \\
\hline & & FRAUD & 7 & 32 & 82.1 \\
\hline & Over & Percentage & & & 83.8 \\
\hline
\end{tabular}

Source: SPSS 23 Output Results, 2020 
In Table 5, the results of this classification table show the predictive power of the model where the predictive value of an indication of financial report fraud (Fraudulent Financial Reporting) with category 1 (FRAUD), there are 38 financial reports, from the observation line it is predicted that 6 financial reports do not indicate report fraud. financial statements (NON FRAUD) and 32 financial reports $(82.1 \%$ ) which are predicted to indicate fraudulent financial reporting. While the predictive value of nonindication of financial statement fraud, with category 0 (NON FRAUD), there are 42 financial reports, from the observation line it is predicted that 35 financial reports $(85.4 \%)$ are predicted not to indicate fraud in financial statements (NON FRAUD) and 7 financial reports where there are indications of fraudulent financial statements. So it can be concluded that the overall classification accuracy is $83.8 \%$.

\section{Discussion of Research Results The Effect of Pressure on Fraudulent Financial Statements}

The results of variable pressure testing with proxy financial stability have a significance value of 0.000 smaller than $a=0.05$. The resulting Beta coefficient value is 8.595. This shows that hypothesis $1 \mathrm{a}(\mathrm{H} 1 \mathrm{a})$ is accepted, so it can be concluded that financial stability has a significant positive effect on the potential for fraudulent financial reporting. The relationship between financial stability (ACHANGE) and fraud on financial statements in this study means that when the financial stability of a company is not in an unstable condition, fraud in financial statements will increase. Investors, creditors, and the public will have more preferences for companies that have good financial stability. When the company's financial condition is not in a stable condition, the company's performance will be doubted and considered inadequate, so that it will hamper the flow of funds from investors in the future. This is according to Skousen et. al., (2009) which states that the greater the change in total assets of a company, the higher the potential for financial statement fraud. The results of this study are also supported by research conducted by Sihombing and Rahardjo (2014) and Siddiq et.al., (2017) which state that financial stability has a significant positive effect on fraudulent financial statements.

The results of external pressure testing with proxy leverage have a significance value of 0.162 which is greater than $a=0.05$. The resulting beta coefficient value is 2.794. This indicates that hypothesis $1 \mathrm{~b}(\mathrm{H} 1 \mathrm{~b})$ is rejected, so it can be concluded that external pressure has an insignificant positive effect on the potential for fraudulent financial reporting. In terms of external pressure. The results of this study support the research results of Ulfah et. al., (2017), but does not support the results of research from Tessa and Harto (2016) and Sihombing and Rahardjo (2014) which show different results that external pressure (LEV) affects financial statement fraud. When companies with high leverage ratios need additional capital to keep the company competitive, instead of cheating on financial statements to meet credit requirements from third parties (creditors), the company will look for other options such as issuing shares to obtain additional capital.

\section{Effect of Opportunity on Fraudulent Financial Statements}

The opportunity variable is measured using effective monitoring and the nature of industry. The results of the effective monitoring test have a significance value of 0.149 greater than $a=0.05$. The resulting Beta coefficient value is 5.865. This indicates that hypothesis $2 \mathrm{a}(\mathrm{H} 2 \mathrm{a})$ is rejected, so it can be concluded that ineffective monitoring has an insignificant positive effect on the potential for fraudulent financial reporting. The test results from the nature of industry have a significance value of 0.046 which is smaller than $a=0.05$. The resulting Beta coefficient value is $-16,239$. This shows that hypothesis $2 \mathrm{~b}(\mathrm{H} 2 \mathrm{~b})$ is rejected, so it can be concluded that the nature of industry has a significant negative effect on fraudulent financial reporting.

Based on the results of the logistic regression test that has been carried out, it can be concluded that ineffective monitoring as measured by the ratio of the number of independent boards of commissioners to total commissioners (BDOUT) has a positive and insignificant effect on fraudulent financial statements, so Hypothesis $2 \mathrm{a}$ (H2a) in this study this is rejected. Hypothesis 2a (H2a) indicates that the value of ineffective monitoring has no effect on financial statement fraud. The results of this study support the results of research from Tessa and Harto (2016), Apriliana and 
Agustina (2017) which state that ineffective monitoring has no effect on the potential for financial statement fraud. The ineffective monitoring is not influential because the effectiveness of a supervisory system in the company cannot only be seen from the number of independent commissioners, because the appointment of independent commissioners may only be to fulfill the regulations set by the Indonesia Stock Exchange which recommends companies to have a minimum number of independent commissioners. $30 \%$ of the total number of commissioners of the company, however, is not intended to improve Good Corporate Governance in the company, so that in practice they can still be intervened by the company. When the independent board of commissioners can be intervened by management, they lose their independence, so the supervisory function will not be effective.

Based on the results of the logistic regression test that has been carried out, it can be concluded that the nature of industry calculated by the ratio of changes in total inventory has a significant negative effect on fraudulent financial statements, so that Hypothesis $2 \mathrm{~b}(\mathrm{H} 2 \mathrm{~b})$ in this study is rejected. The greater the value of the ratio of changes in total inventory, the lower the potential for financial statement fraud to occur. Likewise, the lower the ratio of changes in the total inventory of a company, the potential for financial statement fraud increases. The results of this study do not support the research results of Ardiyani and Utaminingsih (2015) which state that the nature of industry as measured by inventory turnover has no effect on the potential for financial statement fraud.

Management will increasingly have the potential to commit fraud when the company's total inventory is low. This happens because the lower the company's total inventory, it will increase the company's Cost of Good Sold so that the resulting profit is low. To increase the ability to generate profits, a low total inventory can be used as overstatement by management, so that the Cost of Good Sold decreases and the resulting profit increases.

\section{The Effect of Rationalizations on Financial Statement Fraud}

The test results of total accruals have a significance value of 0.007 smaller than $\mathrm{a}=0.005$. The resulting beta coefficient value is 17.326. This indicates that hypothesis 3 (H3) is accepted, so it can be concluded that total accruals have a significant positive effect on fraudulent financial reporting.

Rationalizations are measured by total accruals. Based on the results of the logistic regression test that has been carried out, it can be concluded that total accruals have a significant positive effect on fraudulent financial statements, so that Hypothesis 3 (H3) in this study is accepted. The greater the total accrual value, the higher the potential for fraudulent financial statements.

According to Sihombing and Rahardjo (2014), the total accrual varies from company to company depending on the decisions of each management regarding certain applicable policies. So that when the accrual is higher than cash, it is considered that there is manipulation of income. Therefore, total accruals can be used by management to rationalize the use of accrual principles and management's objective assessment and decision making. (Skousen, 2009).

\section{Effect of Capability on Fraudulent Financial Statements}

The test results of the change in director (change in director) have a significance value of 0.434 which is greater than $a=0.05$. The resulting beta coefficient value is 0.508. This indicates that hypothesis $4(\mathrm{H} 4)$ is rejected, so it can be concluded that change in director has an insignificant positive effect on the potential for fraudulent financial reporting. Based on the results of the logistic regression test that has been carried out, it can be concluded that the change in director has a positive and insignificant effect on fraudulent financial statements, so that Hypothesis 4 (H4) in this study is rejected. The results of this study support the results of research from Tessa and Harto (2016) and Ulfah et.al, (2017) which state that change in directors has no effect on financial statement fraud . 


\section{CONCLUSION AND SUGGESTIONS}

Based on the results of the analysis that has been done, it can be concluded that:

1. The variable Pressure as measured by financial stability (H1a) has a significant positive effect on the potential for fraudulent financial reporting and Pressure as measured by external pressure $(\mathrm{H} 1 \mathrm{~b})$ has a positive and insignificant effect on the potential for fraudulent financial reporting.

2. 3The opportunity variable as measured by ineffective monitoring has a positive and insignificant effect on the potential for fraudulent financial reporting. B. The opportunity variable as measured by nature of Industry has a significant negative effect on the potential for fraudulent financial reporting.

3. Rationalizations as measured by total accrual to total assets have a significant positive effect on the potential for fraudulent financial reporting.

4. Capability as measured by change in director has a positive and insignificant effect on the potential for fraudulent financial reporting.

5. Arrogance as measured using the frequent number of CEO's picture in the annual report has a positive and insignificant effect on the potential for fraudulent financial reporting.

\section{Research Limitations}

1. The sample used in this study is very limited, because the number of state-owned companies (BUMN) listed on the Indonesia Stock Exchange tends to be small.

2. The R2 value of the logistic regression test results is still minimal, namely $50.7 \%$ so that there are other variables outside the variables used in this study that have an effect on fraudulent financial statements.

\section{Suggestion}

1. Further research is suggested to increase the sample, not only limited to state-owned companies (BUMN) listed on the Indonesia Stock Exchange (BEI), but the whole BUMN will be better off.

2. Further research is suggested to consider other independent variables outside the variables that have been used in this study.

3. Further research is suggested to use other fraud detection models or researchers can see data on companies that are indicated to have committed fraud and are subject to sanctions from the Financial Services Authority (OJK) and then tested with appropriate variables and theories

\section{REFERENCES}

Annisya, M., Lindrianasari, \& Asmaranti, Y. (2016). Pendeteksian Kecurang Laporan Keuangan Menggunakan Fraud Diamond. Jurnal Bisnis Dan Ekonomi (JBE), Vol. 23 No. 1, $72-89$ ISSN: 1412-3126.

Apriliana, S. \& Agustina, L. (2017). The Analysis of Fraudulent Financial Reporting Determinant through Fraud Pentagon Approach. Jurnal Dinamika Akuntansi, 9(2), 154-165

Ardiyani, S., dan Sri Utaminingsih, N. (2015). Analisis Determinan Financial Statement Melalui Pendekatan Fraud Triangle. Accounting Analysis Journal, 4(1), $1-10$.

Bayagub, A., Zulfa, K., \& Mustoffa, A. F. (2018). Analisis Elemen-Elemen Fraud Pentagon Sebagai Determinan Fraudulent Financial Reporting (Studi Pada Perusahaan Property dan Real Estate Yang Terdaftar di Bursa Efek Indonesia Periode 2014-2016). Jurnal Ekonomi, Manajemen dan Akuntansi-Universitas Muhammadiyah Ponorogo, Vol.2 No.1, 1-11

Cressey, D. R. (1953). Other People's Money: a Study in the Social Psychology of Embezzlement. Glencoe, IL: Free Press.

Crowe. (2011). Putting the Freud in Fraud: Why the Fraud Triangle Is No Longer Enough, IN Howart, Crowe

Ghozali, I. (2013). Aplikasi Analisis Multivariate Dengan Program SPSS (7th 8 ed.). Semarang: BP Universitas Diponegoro. 
Hammood, H., Talab, H., \& Ali, I. S. (2018). Role Of Beneish M-Score Model in Detecting of Earning Management Practice Empirical Study in Listed Banks of Iraqi Stock Exchange. International Journal of Applied Business and Economic Research. Vol. 15 No.23

Husmawati, P., Septriani, Y., Rosita, I., \& Handayani, D. (2017). Fraud Pentagon Analysis in Assessing the Likelihood of Fraudulent Financial Statement (Study on Manufacturing Firms Listed in Bursa Efek Indonesia Period 2013-

2016). International Conferenceof Applied Science on Engineering, Business, Linguistics and Information Technology. 45-51

Jensen, M. C., \& Meckling, W. H. (1976). Theory of the firm: Managerial behavior, agency costs and ownership structure. Journal of Financial Economics, Vol.3

No 4, 305-360. Available athttps://doi.org/10.1016/0304-405X(76)90026-X

Putriasih, K., 'Ni N. T. H., \& Made A. W. (2016). Analisis Fraud Diamond dalam Mendeteksi Financial Statement Fraud: Studi Empiris pada Perusahaan Manufaktur yang Terdaftar Di Bursa Efek Indonesia (BEI) Tahun 2013-2015. eJournal S1 Ak Universitas Pendidikan Ganesha Jurusan Akuntansi Program S1 Vol:6 No:3.

Rini, Viva Y. dan Tarmizi Achmad. 2012. Analisis Prediksi Potensi Risiko Fraudulent Financial Statement Melalui Fraud Score Model. Diponegoro Journal Of Accounting, Vol. 1, No. 1.

Siddiq, F. R., Achyani, F., \& Zulfikar. (2017). Fraud Pentagon dalam Mendeteksi Financial Statement. Journal of Seminar Nasional Dan The 4th Call for Syariah Paper, 1-14-784.

Sihombing, K. S., \& Rahardjo, S. N. (2014). Analisis Fraud Diamond dalam Mendeteksi Financial Statement Fraud: Studi Empiris pada Perusahaan Manufaktur yang Terdaftar di Bursa Efek Indonesia (BEI) Tahun 2010-2012, Diponegoro Journal of Accounting Vol. 03 No. 02. ISSN (Online) : 2337 -3806. NDG

Skousen, C.J. (2009). Detecting and Predicting Financial Stability: The Effectiveness of the Fraud Triangle and SAS N0. 99. Journal of Accounting and Auditing. SSRN (Social Science Research Network), Vol. 13, 53-81.

Tessa, C., \& Harto, P. (2016). Fraudulent Financial Reporting: Pengujian Teori Fraud Pentagon pada Sektor Keuangan dan Perbankan di Indonesia. Journal of Simposium Nasional Akuntansi XIX, Lampung.

Ulfah, M., Nuraina, E., \& Wijaya, A. L. (2017). Pengaruh Fraud Pentagon dalam Mendeteksi Fraudulent Financial Reporting (Studi Empiris pada Perbankan di Indonesia Yang Terdaftar di Bei. Journal of The 9th FIPA: Forum Ilmiah Pendidikan Akuntansi - Universitas PGRI Madiun, Vol. 5 No.1, 399-418- NaN9723.

Wolfe, D. T. \& Hermanson D. R. (2004). The Fraud Diamond: Considering the Four Elements of Fraud. CPA Journal. Vol 74. 